\title{
POPULISME KANAN, ISLAM DAN KONTEKS INDONESIA
}

\author{
Ari A. Perdana
}

\begin{abstract}
Abstrak
Kemenangan Donald Trump di Pilpres AS dan Brexit di Inggris menandai menguatnya sentimen populisme dalam politik elektotral. Sejumlah pemilu di Eropa setelah itu melanjutkan fenomena ini. Menguatnya populisme sebagian disebabkan oleh faktor kesenjangan ekonomi, tapi lebih banyak karena pertentangan kultural. Menguatnya dukungan pada kelompok Islam konservatif di Indonesia memiliki banyak karakteristik serupa dengan tren populisme global.
\end{abstract}

Kata kunci: Populisme, Politik Elektoral, Islam 


\section{Pendahuluan}

Kemenangan Donald Trump di Pilpres AS, dan keinginan kelompok yang ingin Inggris keluar dari Uni Eropa ("Brexit") di referendum Inggris mengejutkan, tapi tidak aneh. Keduanya bagian dari fenomena menguatnya populisme di negara-negara demokrasi Barat. Tren serupa juga menguat di Asia; Narendra Modi dan BJP di India serta Rodrigo Duterte di Filipina adalah dua contoh terakhir. Menguatnya dukungan pada kelompok Islam konservatif di Indonesia memiliki banyak karakteristik serupa dengan tren populisme global.

Sebelum Trump dan Brexit, politisi seperti Marine Le Pen, Geert Wilders, Norbet Hoffer dan penggagas Brexit Nigel Farage sudah lebih dulu masuk ke ranah politik mainstream. Ronald Inglehart dan Pippa Norris $(2016)^{1}$ menyebutkan, perolehan suara partai-partai yang membawa isu populis di Eropa meningkat dari 5\% di tahun 1960an menjadi 13\% di dekade ini, sementara perolehan kursi mereka meningkat dari 4\% menjadi 13\%. Pengaruh partai dan politisi populis tidak terbatas pada perolehan suara tapi pada diskursus yang lebih besar - di Inggris, contohnya, United Kingdom Independent Party (UKIP) bisa menggiring opini publik ke arah kemenangan Brexit.

\section{Anatomi Populisme}

Tidak mudah mendefinisikan populisme. Berbagai literatur yang ada tidak menghasilkan konvergensi definisi. ${ }^{2}$ Cas Mudde, salah satu ilmuwan politik yang studinya tentang populisme cukup banyak dirujuk, mendefinisikan populisme sebagai “posisi politik yang menempatkan 'rakyat kebanyakan' dan 'elit yang korup' dalam posisi antagonistik, dan melihat politik sebagai ekspresi dari keinginan umum rakyat kebanyakan".

Berbagai pemikiran lain melihat populisme sebagai ekspresi politik yang memiliki beberapa elemen. Pertama, antikemapanan, dalam arti mewakili ekspresi kelompok yang merasa termarjinalkan, Kedua, adanya otoritas

1 Inglehart, Ronald dan Pippa Norris (2016). "Trump, Brexit, and the Rise of Populism: Economic Have-Nots and Cultural backlash". Faculty Research Working Paper Series No. RWP16-026, Harvard Kenedy School, Cambridge, MA. URL https://papers.ssrn.com/sol3/papers.cfm?abstract_id=2818659

2 Gidron, Noam, dan Bart Bonikowski (2013). "Varieties of Populism: Literature Review and Research Agenda. Working Paper No. 13-0004, Weatherhead Center for International Affairs, Harvard University, Cambridge, MA. URL https://papers.ssrn.com/sol3/papers.cfm?abstract_id=2459387

3 Mudde, Cas. 2004. 'The Populist Zeitgeist', Government and Opposition, Vol. 39(4), pp. 542-563. 
pemimpin, baik melalui kharisma atau figur personal maupun pesan yang bersifat apokaliptik ("Negara kita bangkrut, kita sedang menuju neraka"4 ). Ketiga perasaan in-group yang kuat, yang dalam banyak hal ditunjukkan dalam sentimen 'kita vs mereka' - garis pembatas bisa berdasarkan kelas atau status ekonomi (seperti di Thailand), penduduk vs imigran, bahkan ras dan agama.

Sebagai catatan, karena beragamnya definisi populisme, kategorisasi partai atau politisi populis juga bisa diperdebatkan. Batas antara populisme dengan klasifikasi politik tradisional (kiri-tengah-kanan atau progresif-konservatif) juga bisa kabur dan dinamis. Beberapa menganggap Bernie Sanders sebagai populis kiri, sementara ada yang mengakategorikannya ke dalam kelompok progresif atau sosial demokrat. Di Amerika Latin, banyak literatur membedakan Chavez dan Morales yang populis dengan Lula dan Roussef di Brazil atau Michelle Bachelet di Chile yang berhaluan sosial demokrat.

Artikel ini tidak akan masuk ke pembahasan yang rigid terkait klasifikasi. Artikel ini juga akan fokus pada fenomena populisme sayap kanan. Alasannya pragmatis: itu adalah fenomena yang terlihat saat ini. Sementara itu, pembahasan mengenai gerakan populis dan progresif kiri sudah cukup banyak, dan di lapangan belum ada hal yang baru secara signifikan.

\section{Mengapa Populisme Menguat?}

Inglehart dan Norris menawarkan dua hipotesis: kesenjangan ekonomi dan pertentangan kultural.

Hipotesis pertama merujuk pada kenyataan bahwa menyusul krisis finansial 2008-09, perekonomian di negara-negara Barat tengah mencari keseimbangan baru. Di saat yang sama, globalisasi ekonomi membuat banyak lapangan pekerjaan, terutama di sektor manufaktur, pindah ke Meksiko, India, bahkan Afrika. Hal yang sama juga terjadi di sektor jasa; revolusi teknologi informasi memudahkan banyak pekerjaan yang tadinya harus dilakukan di Cleveland atau Birmingham kini bisa dilakukan jarak jauh dari pekerja di Mumbai atau Manila.

Menariknya, Inglehart dan Norris berargumen bahwa hipotesis kesenjangan ekonomi bukanlah faktor utama. Keluhan dari pekerja manufaktur yang

4 Pidato kemenangan Trump. URL http://www.vox.com/2016/6/7/11880448/donald-trump-victory-speech-transcript 
kehilangan pekerjaan mungkin menjelaskan mengapa Hillary Clinton kalah di koridor industri antara Philadelphia dan Detroit, atau gerakan “remain” gagal di kota-kota yang pernah menjadi sentra industri. Tapi dalam sampel yang lebih besar di negara yang lebih banyak, dukungan terhadap politisi populis ternyata tidak menunjukkan korelasi kuat dengan tingkat pengangguran, tingkat pendapatan rumah tangga atau status pekerjaan (terdidik/tidak terdidik). Dukungan terhadap populisme juga tidak berkorelasi kuat dengan perasaan subjektif tentang kerentanan ekonomi (economic insecurity).

Selain itu, jika argumen tekanan ekonomi menjadi faktor utama, mengapa populisme yang bangkit bukanlah yang datang dari sayap kiri (selain Syriza di Yunani), yang lebih langsung mengusung soal kesenjangan kelas?

Di sinilah mengapa hipotesis pertentangan kultural (cultural backlash) lebih menjelaskan fenomena dukungan atas populisme. Dalam tiga dekade terakhir, negara-negara Barat memang mengalami perubahan seperti makin tingginya dukungan bagi kelompok minoritas (LGBT, kulit hitam dan Hispanik, imigran), feminisme, multikulturalisme, internasionalisme, dan nilai-nilai lain yang identik dengan political correctness. Nilai-nilai ini mungkin didukung kuat oleh kelompok usia muda, tinggal di perkotaan dan berpendidikan tinggi.

Fareed Zakaria, mengutip Inglehart dan Norris, menambahkan bahwa nilainilai di atas - beberapa menyebutnya sebagai nilai-nilai "kosmopolitan liberal" diterima oleh generasi lebih muda, tapi membuat generasi yang lebih tua merasa tidak aman. ${ }^{5}$ Mereka melihatnya sebagai serangan atas peradaban dan nilai-nilai yang mereka anut selama beberapa dekade. Akibatnya, mereka memberikan dukungan pada partai atau politisi yang mereka anggap bisa menjaga atau nilainilai yang mereka anggap lebih cocok.

Menarik untuk mengaitkan argumen cultural backlash dan menguatnya populisme ala Brexit dan Trump dengan buku Huntington tahun 2004, "Who Are We?"6 Di situ Huntington berpendapat bahwa Amerika adalah sebuah kuali (melting pot) dimana berbagai kultur bertemu. Tapi di dalam kuali berbagai kultur berbeda itu melebur dengan kultur yang selama ini menjadi penyangga identitas masyarakat Amerika yaitu Anglo Saxon Protestan. Huntington mengutarakan kekuatirannya bahwa identitas itu semakin tergerus oleh arus

5 Zakaria, Fareed (2016a). "Populism on the March." Foreign Affairs, Vol. 95 No. 6 (November/December). URL http://dhanaanmedia.com/populism-on-the-march-why-the-west-is-in-trouble/

6 Huntington, Samuel P. (2014). Who Are We?: The Challenges to America's National Identity. New York: Simon\&Schuster. 
imigran yang mempertahankan kultur yang dibawa dan tidak berusaha melebur di kuali identitas.

Buku ini mendapat reaksi keras terutama dari kelompok liberal yang proimigrasi. Menurut mereka, konsep melting pot perlu dipertanyakan relevansinya dan Amerika mungkin lebih menyerupai mangkuk salad dimana berbagai kultur menyatu tanpa kehilangan identitas masing-masing. Saya masih tidak bisa setuju dengan pendapat Huntington. Tapi di sisi lain perdebatan yang terjadi di tahun 2004 itu ternyata masih terus terjadi. Bahkan menangnya Trump yang membawa ide kebijakan "anti imigran" bisa dibilang menjadi serangan balik atas gagasan 'Amerika sebagai mangkuk salad' yang terbuka pada imigran dan multikulturalisme.

Itulah mengapa di AS, banyak pemilih melihat Trump, dengan berbagai kekurangannya, akan lebih tegas dalam menahan gerakan LGBT dan multikulturalisme (baca: makin besarnya komunitas Hispanik dan Islam). Pemilih laki-laki melihatnya sebagai simbol bahwa maskulinisme masih punya tempat di politik Amerika (terutama setelah musisi perempuan makin dominan di ranah music country). Di Inggris, generasi tua yang besar ketika Inggris masih menjadi kekuatan ekonomi, politik dan militer dunia, merasa Uni Eropa mencabut semua status itu. Sementara di Eropa, gelombang imigrasi membuat benturan budaya menjadi terlihat nyata, menyebabkan banyak orang di Prancis, Jerman, Belanda, Skandinavia merasa tidak nyaman bahkan terancam.

\section{Populisme Kanan di Asia dan Populisme Islam di Indonesia}

Fareed Zakaria juga menunjuk migrasi internasional sebagai faktor penting yang membuat dukungan atas populisme menguat. Menurutnya, di negara maju Asia seperti Jepang dan Korea, dimana tingkat migrasi sangat kecil, populisme tidak jadi isu. ${ }^{?}$

Agaknya Zakaria luput melihat bahwa populisme pun menunjukkan tren di Asia. ${ }^{8}$ Beberapa waktu lalu, Thaksin di Thailand membawa gerakan

7 Zakaria, Fareed (2016b). "What's really pushing politics to the right? Immigration." Op-ed di The Washington Post, 8 Desember. URL https://fareedzakaria.com/2016/12/08/the-force-behind-populism-everywhereimmigration/

8 Stewart, Devin T. dan Jeffrey Wasserstrom (2016). "The Global Populist Surge Is More than Just a Western Story-Just Look at Asia". The Diplomat, 10 Desember. URL http://thediplomat.com/2016/12/the-global-populistsurge-is-more-than-just-a-western-story-just-look-at-asia/ 
populisme kiri, meski berlanjut dengan konflik horizontal dan berujung pada pemerintahan militer. Narendra Modi dan BJP di India, ${ }^{9}$ juga Rodrigo Duterte di Filipina, ${ }^{10}$ meski mengusung narasi berbeda, memiliki banyak elemen populis yang membawa mereka memenangkan pemilu.

Narasi populis selalu jadi bagian dalam politik Indonesia. Namun, setelah dua periode kepresidenan Susilo Bambang Yudhoyono yang lebih berwatak teknokratik, Pemilu 2014 menghadirkan dua kandidat yang membawa narasi populisme, meski dengan beberapa perbedaan. Prabowo Subianto adalah contoh kandidat populis text-book: menggambarkan sistem yang ada sebagai rusak dan ia akan memperbaiki semua, serta menyerang kepentingan asing. Joko Widodo menawarkan narasi populisme yang lebih lunak - memperbaiki dari dalam dan menggambarkan diri sebagai figur yang lebih inklusif dan tidak konfrontatif. ${ }^{11}$ Dibandingkan dengan ketika menjadi kandidat, pemerintahan Presiden Joko Widodo menggabungkan narasi populisme dengan pendekatan teknokratik.

Di saat yang sama, ada bentuk populisme yang menguat: populisme Islam, meminjam istilah Vedi Hadiz. ${ }^{12}$ Penggunaan istilah populisme Islam di artikel ini lebih merupakan cara singkat untuk mendefinisikan sebuah tren yang memiliki anatomi mirip dengan populisme (spesifiknya, populisme kanan), sekaligus membawa Islam sebagai identitas kelompok. Istilah populis Islam juga bisa digunakan untuk membedakan dengan Islam radikal, atau Islam politik yang bergerak di jalur politik elektoral.

Mendefinisikan apa dan siapa itu Islam populis bukan hal mudah. Sebagai istilah baru, ini perlu dikaji serta diuji lebih lanjut. Tapi serangkaian aksi "Bela Islam” di penghujung 2016 memberikan sedikit gambaran atas kelompok Islam populis, yang lebih mirip seperti koalisi longgar antara kelompok miskin kota yang tergabung dalam grup-grup vigilant, kelas menengah religius, dan beberapa elit pemuka agama, tokoh politik dan bisnis.

9 "A man of some of the people." The Economist, 28 Desember 2013. URL http://www.economist.com/news/ briefing/21591599-populist-nasty-past-and-decent-economic-record-wants-run-india-man-some

10 Perdana, Ari (2016). "Bagaimana nasib Filipina setelah Duterte?" Op-ed di Rappler Indionesia, 14 Mei. URL http://www.rappler.com/indonesia/133038-bagaimana-nasib-filipina-setelah-duterte

11 Mietzner, Marcus (2015). Reinventing Asian Populism: Jokowi's Rise, Democracy and Political Contestation in Indonesia." Policy Studies No. 72. Honolulu: East-West Center. URL http://www.eastwestcenter.org/publications/ reinventing-asian-populism-jokowis-rise-democracy-and-political-contestation-in

12 Hadiz, Vedi R. (2016). Islamic Populism in Indonesia and the Middle East. Cambridge, UK: Cambridge University Press. 
Aksi-aksi bela Islam menuntut Gubernur DKI Basuki Tjahaja Purnama (Ahok) dipenjarakan karena dianggap "menistakan Islam dan Kitab Suci AlQur'an.” Tapi jika diperhatikan, kasus Ahok lebih menjadi pemicu atau alasan berkumpulnya ratusan ribu orang. Demikian juga, tuntutan untuk membawa kasus Ahok ke ranah hukum hanya merupakan tuntutan antara. Sebagai perbandingan, aksi Tea Party di AS dipicu setelah Obama mengeluarkan paket stabilisasi ekonomi. Tapi faktor-faktor yang menyebabkan gerakan Tea Party muncul sudah ada sebelum, dan terlepas, dari paket stabilisasi ekonomi. Dan tuntutan mereka lebih dari sekedar membatalkan kebijakan itu.

Narasi spesifik yang diangkat oleh populis Islam di Indonesia tentu berbeda dengan populis kanan di AS dan Eropa. Tapi menariknya, dalam banyak hal mereka memiliki anatomi dan elemen yang mirip. Pertama, keduanya merupakan ekspresi dari kelompok yang secara demografis mayoritas tapi merasa termarjinalkan.

Kedua, penggunaan narasi nativism untuk memperkuat identitas gerakan kelompok kulit putih Anglo-Saxon di AS, penduduk asli (vs imigran) di Eropa, umat Islam di Indonesia. Meski isu ras dan agama memang tidak diangkat secara eksplisit di aksi-aksi bela Islam, secara implisit sasaran aksi itu adalah Ahok yang berasal dari etnis Tionghoa dan beragama Kristen. Tapi di luar aksi, sentimen ras, agama dan anti-asing juga semakin sering mewarnai narasi kelompok Islam populis. Contohnya dalam isu pekerja Tionghoa dan beberapa gesekan horizontal terkait pembangunan rumah ibadah.

Kemiripan ketiga, baik di Indonesia, AS maupun Eropa, menguatnya populisme dibantu oleh apa yang disebut sebagai 'post-truth politics'. ${ }^{13}$ Kecepatan dan volume informasi di era digital tidak diimbangi dengan mekanisme verifikasi yang memadai. Akibatnya berita bohong (hoax atau fake news) menjadi cara konsolidasi kelompok. Sebagian ini menjadi strategi yang dimainkan secara sistematis, oleh Steve Bannon lewat Breitbart News di AS yang melapangkan jalan bagi kemenangan Trump, atau pola komunikasi UKIP serta pendukung Brexit yang mendistorsi fakta-fakta soal keuntungan Inggris meninggalkan Uni Eropa. Tapi sebagian besar ini tetap merupakan pola komunikasi spontan yang umum di media sosial.

13 Davies, William. "The Age of Post-Truth Politics". Op-ed di The New York Times, 24 Agustus 2016. URL https:// www.nytimes.com/2016/08/24/opinion/campaign-stops/the-age-of-post-truth-politics.html?_r=0 


\section{Menjelaskan Tumbuhnya Populisme Islam}

Sulit untuk menentukan kapan tren Islam populis dimulai. Vedi Hadiz ${ }^{14}$ dan Wasisto Raharjo Jati ${ }^{15}$ bahkan menarik akar populisme Islam jauh ke era Orde Baru yang merepresi ekspresi politik kelompok Islam.

Yang jelas di awal 2000an, muncul sejumlah kelompok yang membawa identitas agama (Islam), bertindak secara vigilante 'menindak' kegiatan-kegiatan atau tempat-tempat yang dianggap tidak sesuai dengan ajaran Islam - dari diskotik hingga diskusi terkait komunisme atau LGBT. Ada beberapa kelompok, tapi yang paling populer dan berpengaruh adalah Front Pembela Islam (FPI).

FPI dan beberapa kelompok lain yang lebih kecil pada awalnya lebih menggambarkan kelompok vigilante ketimbang gerakan ideologis. Saat itu, kelompok Jamaah Islamiyah (JI), Majelis Mujahidin Indonesia (MMI), Laskar Jihad (LJ) dan Hizbut Tahrir Indonesia (HTI) lebih merepresentasikan gerakan berdasarkan ideologi dan tujuan yang jelas. Perlahan, aktivitas JI, MMI dan LJ berhasil diminimalkan, dan pendekatan radikal yang mereka usung membuat basis dukungan terhadap mereka tidak pernah besar. HTI meski perlahan makin populer, aktivitas mereka masih cenderung ekslusif dan inward-looking.

Hingga awal dekade 2010an, narasi utama Islam politik di Indonesia masih dipegang oleh partai-partai dan politisi Islam. Suara FPI dan semacamnya, meski cukup nyaring, secara umum tidak dilihat sebagai representasi suara Islam kebanyakan. FPI juga lebih dilihat sebagai kelompok yang beranggotakan kelompok miskin dan marginal di perkotaan. Tingginya tingkat pengangguran di kelompok laki-laki usia muda - yang mendorong pecahnya Arab spring ${ }^{16}$ - juga menjelaskan mengapa ormas seperti FPI mudah merekrut anggota. ${ }^{17}$ Dengan kata lain, mereka bergerak atas motivasi ekonomi dan mencari identitas sosial, ketimbang ideologi.

14 Hadiz, Vedi R. (2014). "A New Islamic Populism and the Contradictions of Development." Journal of Contemporary Asia Vol. 44(1). URL http://dx.doi.org/10.1080/00472336.2013.832790

15 Jati, Wasisto Raharjo (2013). "Radicalism in the Perspective of Islamic-Populism: Trajectory of Political Islam in Indonesia." Journal of Indonesian Islam Vol. 07(02), Desember. URL http://jiis.uinsby.ac.id/index.php/Jlls/article/ viewFile/129/128

16 Malik, Adeel (2011). "The Economics of Arab Spring." Al-Jazeera, 13 Oktober 2011. URL http://www.aljazeera. com/indepth/opinion/2011/10/20111010142425419849.html

17 Perdana, Ari (2012). "Penganggur Usia Muda dan Pasar Kerja." Majalah Tempo, 13 Desember 2012. URL http:// koleksiartikel.blogspot.com/2012/12/penganggur-usia-muda-dan-pasar-kerja.html 
Setidaknya hingga menjelang dan selama Pilkada DKI 2017, dukungan terhadap FPI dari kelompok kelas menengah semakin besar. Sejak 1990an, kelas menengah religius - kelas menengah yang mengidentikkan diri dengan agama (Islam) sebagai indentitas - memang menunjukkan kecenderungan meningkat, baik dari segi jumlah maupun ekspresi sosial, politik dan budaya. Awalnya, kelas menengah religius ini tidak ingin diasosiasikan dengan Islam yang ekstrem atau radikal. Namun dalam beberapa tahun terakhir, dan khususnya di aksi-aksi bela Islam 2016, kelompok ini terlihat cukup nyaman diasosiasikan dengan, atau berada dalam satu kelompok besar bersama FPI.

Ini membuat populisme Islam di Indonesia, seperti populisme Trump, Brexit dan lainnya di Eropa, menunjukkan karakter lintas-kelas. Menjadi menarik untuk memahami lebih jauh mengapa populisme Islam juga menjadi fenomena kelas menengah. Menurut Hadiz, ini menunjukkan bahwa kelas menengah di Indonesia juga memiliki frustrasi dan perasaan tidak aman dalam persaingan di era kapitalisme global.

Pertanyaannya, apakah frustrasi dan perasaan tidak aman itu semata terkait faktor ekonomi? Atau itu juga menunjukkan penolakan mereka atas nilai-nilai kosmopolitan liberal, seperti Inglehart dan Norris temukan di AS dan Eropa?

\section{Lalu Bagaimana?}

Tulisan ini dibuat menjelang Pilkada DKI tahun 2017. Pilkada berakhir dengan keberhasilan Anies Baswedan mengalahkan gubernur petahana Basuki Tjahaja Purnama. Secara umum hasil Pilkada 2017 menjadi contoh empiris bagaimana sentimen populisme Islam bisa membawa sukses secara elektoral. Tidak berhenti di situ, setelah Pilkada selesai pengadilan menjatuhkan vonis penjara kepada Basuki atas tuduhan penistaan agama.

Di Eropa, dua pemilihan umum di Belanda dan Prancis yang terjadi di awal 2017 memberi sedikit kelegaan. Hasil kedua pemilihan umum itu menunjukkan bahwa gelombang populisme kanan yang sukses membawa kemenangan Brexit di Inggris dan Donald Trump di AS tahun 2016 tidak berlanjut. Geertz Wilders di Belanda dan Marine Le Pen di Prancis, dua tokoh yang selama beberapa tahun terakhir membangun kampanye di atas isu nativis dan identitas, tidak berhasil merebut suara terbanyak. 
Meski demikian, hasil pemilu di kedua negara itu perlu dibaca lebih dalam dari sekedar hasil akhir. Di Belanda, Partij voor de Vrijheid (PVV) pimpinan Wilders mendapat 20 kursi dari 150 kursi di parlemen. Ini menjadikan PVV partai kedua terbesar di parlemen setelah Volkspartij voor Vrijheid en Democratie (VVD) pimpinan petahana Mark Rutte yang mendapatkan 33 kursi. Dan perolehan 20 kursi VVD adalah kenaikan sebanyak 5 kursi dari pemilu 2012.

Artinya, Wilders tidak sepenuhnya gagal. Sejak awal ia paham bahwa andaipun PVV mendapat suara terbanyak, hampir tidak ada peluang Wilders menjadi Perdana Menteri. Sulit bagi partai manapun di Belanda membentuk pemerintahan tanpa koalisi. Dan tidak ada partai yang berminat membangun koalisi bersama PVV. Dengan berada di luar pemerintahan, Wilders bisa leluasa terus memainkan isu populisme tanpa perlu dipusingkan dengan urusan teknis pemerintahan seperti yang dihadapi Trump dan para proponen Brexit sekarang.

Berbeda dengan pemilu Belanda dimana sistem yang ada membuat tidak ada pemenang mutlak, pemilihan presiden di Prancis adalah kontes yang lebih ketat dan winner takes it all. Di putaran pertama tidak ada kontestan yang merebut suara terbanyak. Di putaran kedua, Emmanuel Macron mengalahkan Marine Le Pen dengan suara dua kali lebih banyak.

Dilihat secara terpisah, kemenangan Macron cukup fenomenal. Di usia 39 tahun dengan partai yang belum lama dibentuk, ia bisa menjadi pemimpin salah satu negara terbesar di Eropa. Meski jika dilihat secara keseluruhan, narasi utama dalam pemilu Prancis masih tetap berpusat pada Le Pen. Tepatnya, dorongan untuk tidak menjadikan Le Pen presiden. Dan fakta bahwa Le Pen masih tetap bisa mendorong pemilihan presiden hingga dua putaran, dan mendapatkan sekitar sepertiga suara, menunjukkan bahwa fenomena menguatnya populisme kanan dalam politik elektoral masih tetap perlu diperhatikan.

Momentum populis kanan kembali ketika pemilu Austria di tahun 2017 memaksa Österreichische Volkspartei (ÖVP), partai penguasa yang berhaluan konservatif moderat, berkoalisi dengan partai populis kanan Freiheitliche Partei Österreichs (FPÖ). Pemilu Italia di tahun 2018 berujung dengan lahirnya koalisi dua partai populis kanan, Movimento 5 Stelle (M5S) dan Lega Nord (LN) di pemerintahan. Di tahun yang sama, pemilu Hungaria mengukuhkan Victor Orban kembali menjadi Perdana Menteri. Orban, seperti halnya M5S, LN dan FPÖ, mengusung jargon nativisme dan anti-imigran.

Jika populis kanan relatif berhasil merebut momentum, kinerja partai dan 
politisi yang berhaluan populis kiri di Eropa tidak terlalu bagus. Di Spanyol, koalisi Unidos Podemos tidak berhasil memperpanjang mandat mereka di pemilu 2019. Pemilu Yunani baru akan dilakukan bulan Juli 2019, tapi berbagai survey menujukkan turunnya dukungan terhadap Syriza.

Dua raksasa Asia, India dan Indonesia baru melaksanakan pemilu di tahun 2019. Narendra Modi di India berhasil memperpanjang mandatnya dengan kembali memainkan sentimen nasionalis Hindu. Sebaliknya, kemenangan Joko Widodo di Indonesia memberi harapan bahwa populisme Islam yang dimainkan oleh penantangnya, Prabowo Subianto, tidak cukup kuat untuk memberi kemengan elektoral di tingkat nasional. Meski demikian, bukan berarti populisme Islam tidak bisa berhasil di pemilu berikut, atau di tingkat daerah. Narasi Islamis yang sudah begitu kuat dimainkan sejak 2014 (dan berhasil di Pilkada DKI 2017) tidak akan mudah dibalikkan begitu saja. ${ }^{18}$

Artikel ini lebih merupakan observasi umum ketimbang hasil riset yang mendalam. Ini bisa ditindaklanjuti dengan studi atau survey yang bisa mengkonfirmasi beberapa hal. Pertama, seberapa tinggi sebenarnya dukungan terhadap populisme Islam (dengan proxy aksi-aksi bela Islam dan aktor-aktornya) di kalangan kelompok kelas menengah terdidik, dibandingkan dengan kelompok lainnya. Kedua, seberapa besar hipotesis kesenjangan ekonomi dan pertentangan kultural menjelaskan menguatnya tren Islam populis di Indonesia. Ketiga, apakah 'koalisi' antara kelas menengah, kelompok miskin kota yang tergabung dalam ormas-ormas agama serta elit-elit pemuka agama pada aksi-aksi bela Islam lalu bersifat cair dan hanya sesaat, atau relatif permanen?

Membandingkan fenomena yang terjadi di berbagai negara, terlihat bahwa ada banyak kesamaan anatomi dalam populisme Islam dan populisme kanan di Amerika serta Eropa. Ini bisa diartikan bahwa identitas Islam yang diusung di Indonesia memiliki fungsi yang mirip dengan identitas nativist lain. Ungkapan 'bela Islam' juga memiliki nada yang sama dengan 'make America great again', 'make Mexico pays' atau 'UK first.'

Yang masih berbeda adalah soal kepemimpinan. Di Eropa daratan, populisme kanan dipimpin oleh politisi di jalur formal seperti Le Pen atau Wilder. Di Inggris, populisme ala Brexit digagas oleh UKIP pimpinan Nigel Farage yang sebenarnya bukan bagian dari partai-partai utama. Namun mereka bisa

18 Slater, Dan dan Maya Tudor (2019). "Why Religious Tolerance Won in Indonesia but Lost in India?" Foreign Affairs, 3 Mei 2019. https://www.foreignaffairs.com/articles/india/2019-07-03/why-religious-tolerance-wonindonesia-lost-india 
menggiring opini publik, dan Partai Konservatif sekalipun terbawa ikut ke isu yang mereka angkat. Di AS, Donald Trump memang maju sebagai kandidat Partai Republik, tapi ia adalah figur di luar sistem. Tapi narasi yang ia angkat mendatangkan dukungan terutama dari kelompok alt-right. Ini membuat Partai Republik, yang sudah lebih dulu digoyang dari dalam oleh gerakan populis Tea Party, terbawa permainan yang dibuat oleh Trump dan kelompok populis.

Jika kecenderungan populisme Islam berlanjut dan semakin kuat, maka tren kemenangan populis kanan dalam proses elektoral di AS, Inggris, juga India, bisa berlanjut ke Indonesia. Ini tentu pukulan berat untuk mereka (kita) yang masih percaya bahwa Indonesia harus berdiri di atas penghargaan atas keberagaman. Sejarah Eropa juga menunjukkan, populisme yang berawal dari gerakan di luar sistem, sangat rentan berubah menjadi fasisme begitu ia mendapat mandat elektoral. ${ }^{19}$

Tulisan ini merupakan pengembangan dari artikel penulis di Harian Indoprogress, 23 Januari 2017

19 Berman, Sheri. "Populism Is Not Fascism - But It Could Be a Harbinger." Foreign Affairs Vol. 95 No. 6 (November/December). URL https://www.foreignaffairs.com/articles/united-states/2016-10-17/populism-notfascism 


\section{Daftar Pustaka}

"A man of some of the people." The Economist, 28 Desember 2013. URL http://www.economist.com/news/briefing/21591599-populist-nastypast-and-decent-economic-record-wants-run-india-man-some

Berman, Sheri. "Populism Is Not Fascism - But It Could Be a Harbinger." Foreign Affairs Vol. 95 No. 6 (November/December). URL https://www. foreignaffairs.com/articles/united-states/2016-10-17/populism-not-fascis

Davies, William. “The Age of Post-Truth Politics”. Op-ed di The New York Times, 24 Agustus 2016. URL https://www.nytimes.com/2016/08/24/opinion/ campaign-stops/the-age-of-post-truth-politics.html?_r=0

Gidron, Noam, dan Bart Bonikowski (2013). "Varieties of Populism: Literature Review and Research Agenda. Working Paper No. 13-0004, Weatherhead Center for International Affairs, Harvard University, Cambridge, MA. URL https://papers.ssrn.com/sol3/papers.cfm?abstract_id=2459387

Hadiz, Vedi R. (2016). Islamic Populism in Indonesia and the Middle East. Cambridge, UK: Cambridge University Press.

Hadiz, Vedi R. (2014). "A New Islamic Populism and the Contradictions of Development.” Journal of Contemporary Asia Vol. 44(1). URL http:// dx.doi.org/10.1080/00472336.2013.832790

Huntington, Samuel P. (2014). Who Are We?: The Challenges to America's National Identity. New York: Simon\&Schuster.

Inglehart, Ronald dan Pippa Norris (2016). "Trump, Brexit, and the Rise of Populism: Economic Have-Nots and Cultural backlash”. Faculty Research Working Paper Series No. RWP16-026, Harvard Kenedy School, Cambridge, MA. URL https://papers.ssrn.com/sol3/papers. cfm?abstract_id=2818659

Jati, Wasisto Raharjo (2013). "Radicalism in the Perspective of Islamic-Populism: Trajectory of Political Islam in Indonesia.” Journal of Indonesian Islam Vol. 07(02), Desember. URL http://jiis.uinsby.ac.id/index.php/JIIs/article/ viewFile/129/128 
Malik, Adeel (2011). "The Economics of Arab Spring." Al-Jazeera, 13 Oktober 2011. URL http://www.aljazeera.com/indepth/ opinion/2011/10/20111010142425419849.html

Mietzner, Marcus (2015). Reinventing Asian Populism: Jokowi's Rise, Democracy and Political Contestation in Indonesia." Policy Studies No. 72. Honolulu: East-West Center. URL http://www.eastwestcenter.org/publications/ reinventing-asian-populism-jokowis-rise-democracy-and-politicalcontestation-in

Mudde, Cas. 2004. 'The Populist Zeitgeist', Government and Opposition, Vol. 39(4), pp. 542-563.

Perdana, Ari (2016). “Bagaimana nasib Filipina setelah Duterte?” Op-ed di Rappler Indionesia, 14 Mei. URL http://www.rappler.com/indonesia/133038bagaimana-nasib-filipina-setelah-duterte

Perdana, Ari (2012). "Penganggur Usia Muda dan Pasar Kerja." Majalah Tempo, 13 Desember 2012. URL http://koleksiartikel.blogspot.com/2012/12/ penganggur-usia-muda-dan-pasar-kerja.html

Slater, Dan dan Maya Tudor (2019). "Why Religious Tolerance Won in Indonesia but Lost in India?" Foreign Affairs, 3 Mei 2019. https://www. foreignaffairs.com/articles/india/2019-07-03/why-religious-tolerance-wonindonesia-lost-india Pidato kemenangan Trump. URL http://www.vox. com/2016/6/7/11880448/donald-trump-victory-speech-transcript

Stewart, Devin T. dan Jeffrey Wasserstrom (2016). "The Global Populist Surge Is More than Just a Western Story-Just Look at Asia". The Diplomat, 10 Desember. URL http://thediplomat.com/2016/12/the-global-populistsurge-is-more-than-just-a-western-story-just-look-at-asia/

Zakaria, Fareed (2016a). "Populism on the March." Foreign Affairs, Vol. 95 No. 6 (November/December). URL http://dhanaanmedia.com/populismon-the-march-why-the-west-is-in-trouble/

Zakaria, Fareed (2016b). "What's really pushing politics to the right? Immigration." Op-ed di The Washington Post, 8 Desember. URL https://fareedzakaria.com/2016/12/08/the-force-behind-populismeverywhere-immigration/ 